\title{
骨関節疾患に対する漢方薬の利益性効果
}

\section{岸田 友紀}

要約：骨関節とは，身体運動に関わる骨・筋肉・関 節・神経などの総称を指す。骨関節疾患に関連した 様々な症候のうち, 漢方薬が適応となるのは, 変性疾 患・骨量低下・筋肉の減弱・神経活動の低下などを基 盤としており，その多くは疼痛が慢性化している。骨 関節疾患には，炎症・熱感を生じるものと，冷えによ って増悪するものの両者が存在する．漢方薬の利点と して, 生薬の組み合わせを工夫することで体感温度を 変化させ，これらの症状に対処できることが挙げられ る.また, 漢方薬は, 多種類の生薬を組み合わせた薬 凨のため, 多彩な薬効を示す。 そのため, 主訴だけで はなく，時には患者が意識していなかった心身の不具 合を改善したり，一片で多岐にわたる症状を改善した りすることが可能である。これも，骨関節疾患に漢方 薬を応用する利点となる。本稿では, 個々の症例を通 して, 骨関節疾患に漢方薬を使う意義についてまとめ る.

\section{1.はじめに}

漢方薬は, 古典を基盤として多種類の生薬から構成 されており，古くから伝承されてきたものである，漢 方薬が, 現代においても尚残っているということは, すなわち, 多くの人々が遭遇する病態に対して効果が ある，というあかしでもある。

骨関節疾患は各年齢層の誰もが, 程度の差はあれ経 験する病態である。現代に抢いて, 骨関節疾患の治療 に, 貼付剤や鎮痛薬などの西洋薬が中心的な役割を果 たすことは間違いないが，連綿と生き残っている漢方 薬にもその存在意義がある. 漢方薬にしかない利点を 知ることが，骨関節疾患に漢方薬を用いる意義への理 解につながると考え，本稿を記した。

\section{2. 骨関節疾患の特徵と漢方薬}

日本整形外科学会によれば，骨関節とは，身体運動 に関わる骨・筋肉・関節・神経などの総称であり, 運 動器とも呼ばれる.

運動器の障害は, 関節そのもの, あるいは筋肉や腱 などの関節周囲など, 部位によって機能障害の程度は 様々であるが，その多くは痛みを伴う。ささらに，骨・ 軟骨などの変性を原因とする疾患が多いため, 加齢に 伴って罹患率が上昇する傾向にある.

保存治療を適応とする骨関節疾患は，11多くは痛み を伴う，(2)慢性化していることが多い，(3)老化を基盤 としている場合, 運動器のみならず他部位の症状を併

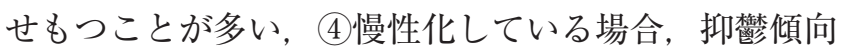
などの精神症状を併せ持つことが多い(1), といった 背景がある，従って，これらを熟慮して投薬治療を行 う必要がある。

整形外科領域では，鎮痛を主とした西洋薬を用いら れることが多く，その除痛効果が優れていることは論 を待たない，では，骨関節疾患に，わざわざ漢方薬を 用いる利点とは何であろうか，骨関節疾患に漢方薬を 使う意義を, 症例を振り返りながらまとめる.

\section{1）症例 [1］30 代の女性 不定愁訴}

(1)現病歴： 3 年前より誘因なく右膝の裏の痛みが生 じた，膝の屈曲時に痛みが強くなり，同部位に圧痛が あった. 整形外科を受診し, レントゲンと MRIの撮像 を行ったが，異常は指摘されず，鎮痛剤と湿布を処方 された. しかし, 痛みの改善が得られないため, 各整 形外科を転々として当院漢方外来を紹介初診となった。

(2)初診時：膝の裏の痛みは相変わらずで, もう治ら ないのではないかと意気消沈していた。痛みの増悪は, 寒い日・月経時・雨天時である。他に, 月経痛と, 冬

キーワード : 骨関節疾患, 漢方薬, 体温, 高齢者, 不定愁訴

大阪大学大学院 医学系研究科 漢方医学寄附講座 (

E-mail: yu-kishida@umin.ac.jp＼cjkstart原稿受領日：2013 年 9 月 30 日, 依頼原稿

Title: The efficacy of Kampo medicine for the diseases and joint pain Author: Yuki Kishida 
になると指先がしびれるように痛むなどの強い冷えも 合併していた.

(3)経過：当帰芳薬散と附子末帮を処方したところ，は じめて痛みを感じずに過ごすことができ，月経痛や冷 えも改善したとのことであった。

(4)処方解説 : 当帰药薬散は, 当帰・师芦芦で月経調節

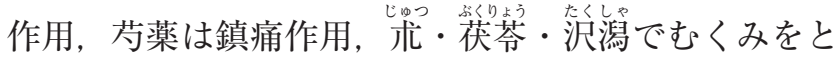
る処方構成である。したがって，月経時に何か体の卜 ラブルが起きやすい場合によく用いられる。附子末の 鎮痛作用は，坐骨神経痛モデルマウスを用いた検討で， 用量依存的な疼痛閾値の上昇を示すことがわかってい る．また，アロディニア（通常では痛みと感じないわ ずかな刺激が疼痛として認識される感覚異常をしめす 病態）に対する効果も報告されている(2). また, 附子 末の服用で皮膚温が改善していることも報告されてい る(3)。これらのことから分かるように, 附子末は, 温 熱・鎮痛作用があるため, 冷えて痛むような症状に適 応といってよい.

(5)本症例で考える漢方薬の利点: 温熱効果, および 主訴以外の症状（月経痛・冷え）が緩和できたのは, 西洋薬でのアプローチでは得られなかった点であろう。

\section{2）症例 [2] 30 代女性 頸椎椎間板ヘルニア}

(1)現病歴：2 力月前より, 期日が迫った仕事がある と, 肩こりと頭痛が激しくなることを自覚した。整形 外科医を受診し, MRI で軽い頸椎椎間板ヘルニアを指 摘され，鎮痛剤や貼付剤を処方された。これらの薬で 効果はあるものの，毎日鎮痛剤を飲むのは抵抗があり， 他に方法はないかと当院の漢方外来を紹介初診となっ た.

(2)初診時：痛みは午後から激しくなることが多く, 毎日鎮痛片を服用しなければ仕事ができないという状 況であった. 自己判断で葛根湯を服用していたが, 効 果はなかった，痛みは，しなければならない仕事が沢 山ある時に増強し, カイロを貼ったり, 週末になると 軽減するということであった，他に気になることとし ては，仕事上のストレスをよく感じており，子供に当 たってしまって自己嫌悪に陥ることが多いということ であった。

(3)経過 : 抑加肝散の処方により痛みは改善した。本人 の弁によると,「4 回服用してから, 肩こり・頭痛がな いことに気づいた」,「服用していて 2 週間の間, 鎮痛 剤を服用したのは 1 回だけになった」であった。他に も,「抑肝散を服用してから気分的に楽になり, 子供に あたらなくなった」という変化があったという。1カ 月半の抑肝散服用後, 鎮痛剂服用は皆無になった。

(4)処方解説 : 抑肝散は, 脳内でグルタミン酸濃度の
上昇を抑えて精神症状を改善させることが報告されて おり, 疼痛領域でも処方されることのある漢方薬であ る(4). 本症例に効果の見られなかった暮根湯は, 体 を温める桂枝湯に麻黄が加わることで発汗作用を持ち, 肩こりを治す作用の葛根が入った処方構成となってい る．即ち，温めて肩こりを治す方㓮である，肩こりや 頭痛で葛根湯を処方するケースは多いが，本症例のよ うに葛根湯ではなく抑肝散が奏功する肩こりや頭痛は, 主に精神的なストレスによる影響を強く受けたための ものと考えられる.

(5)本症例で考える漢方薬の利点：痛みの改善だけで なく、「気分的に楽になった」と本人が言うように精神 症状の改善がみられた点が挙げられる。

\section{3）症例 [3] 当院の整形外科学講座と共同で行った研究}

(1)内容: 人工股関節置換術は, 疼痛・関節可動域 · 歩行能力・QOLの改善をもたらす優れた治療方法で あるが, 合併症として下肢腫脹・深部静脈血栓症が挙 げられる. 静脈の鬱滞・深部静脈血栓は 40\% 60\%, 肺塞栓は $1.5 \%$, 死亡が $0.4 \%$ と報告されている. 予防 方法として，下肢の挙上・弾性ストッキング・間欠的 空気圧迫法・早期離床が挙げられているが, 発生率を 皆無にすることはできない.またへパリン製剤投与も 選択肢の一つであるが, 術後の出血量に注意して用い る必要がある。

このように, 術後の下肢腫脹・深部静脈血栓症は, 整形外科医が気を遣う合併症の一つであるが，我々は， 柴苓湯という漢方薬がむくみ・浮腫を軽減させるとい うことに着目し, 人工股関節置換術前後の服用で軽減 できないか, 前向き研究を行った。具体的には, 人工 股関節置換術を行った症例を柴苓湯服用群と, 非服用 群の 2 群にわけて, 術後の下腿最大周囲径と CRPの推 移を調べた。下腿周囲径をみると，柴苓湯を服用する と浮腫の軽減時期が早いことが分かった（図 1)。また, 柴苓湯の服用によって CRP の陰性化が有意に早くな ることも分かった（図 2). 作用機序としては, 柴苓湯 に含まれる童苓散によるアルドステロンやアクアポリ ン発現減少を介して浮腫を抑制することや, サイコサ ポニンが necrose factor $(\mathrm{NF} \kappa \mathrm{B})$ を抑制することによ ると考えられる(図 3) (5).

(2)本症例で考える漢方薬の利点 : 前述したように下 肢の挙上・弾性ストッキング・間欠的空気圧迫法・早 期離床・ヘパリン製剂でも下肢の腫脹は軽快する。し かし, CRPの早期陰性化といった，プラスアルファの 作用は漢方薬にしかないものである. 即ち, 漢方薬以 外に代替薬がないと言ってよいだろう。 


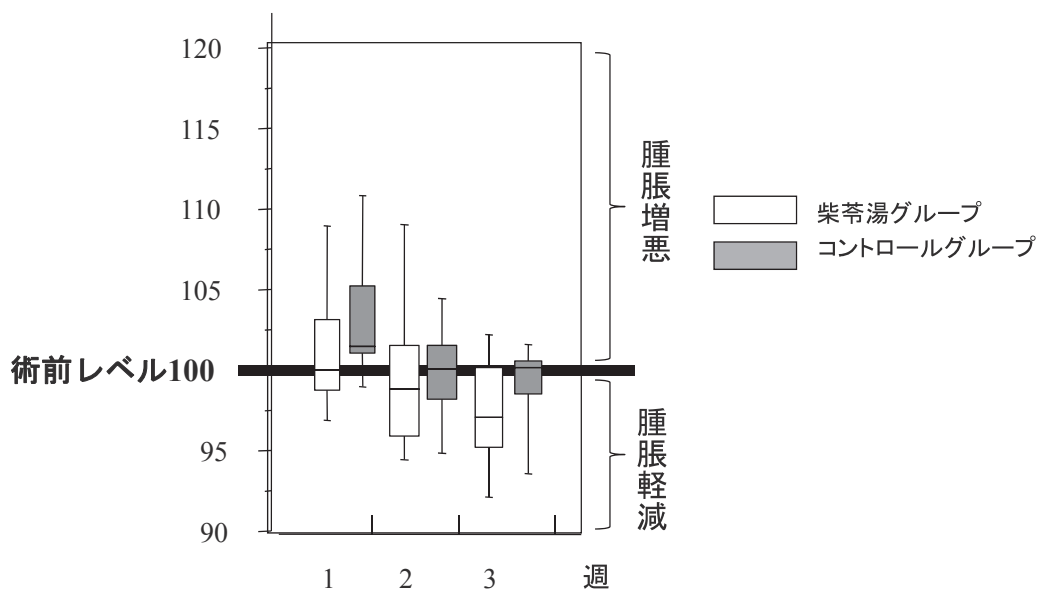

図 1 人工股関節置換術後, 下腿最大周囲径の変化

(大阪大学大学院医学系研究科漢方医学寄附講座ホームページ改变)

\section{$\operatorname{CRP}(\mathrm{mg} / \mathrm{dl})$}

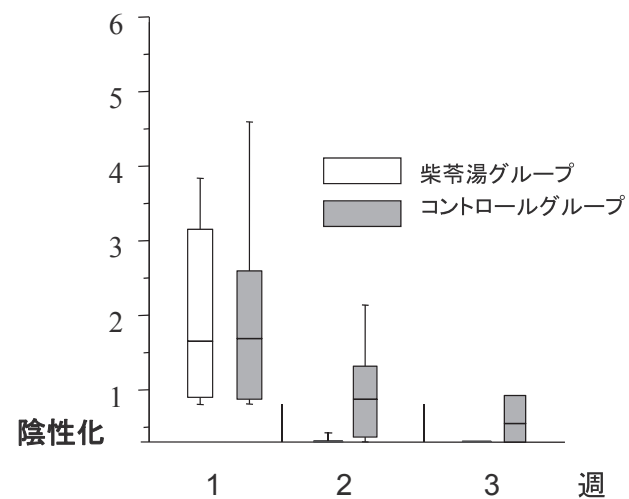

図 2 人工股関節置換術後, CRP の变化

(大阪大学大学院医学系研究科漢方医学寄附講座木ームページ改变)

\section{3. 骨関節疾患に対する漢方薬の役割}

前項であげた症例から，骨関節疾患に，西洋薬では なく漢方薬を用いる意義を考える.

まず，[1]で述べた症例のように，「冷えが解消され， 痛みがとれた」というように, 漢方薬を用いて体感温 度を上げることができる点が挙げられる，腫脹や炎症 が激しい症例では, 逆に漢方薬の服用によって冷やす こともできる. 西洋医学的アプローチでは, 皮膚に直 接貼付・塗布するなどで局所の温度を変化させること になるが，全身あるいは体の内部温度の異常を感じて いるような場合は, こういった手法での解決は不可能 である，その点，漢方薬では服用によって体感温度を 変化させることが可能である，具体的に言えば，冷え の自覚が強い場合は生姜・附子・細辛・㣎莱莫などの 入った漢方薬を, 熱感を伴っていれば, 宕亳・黄連・

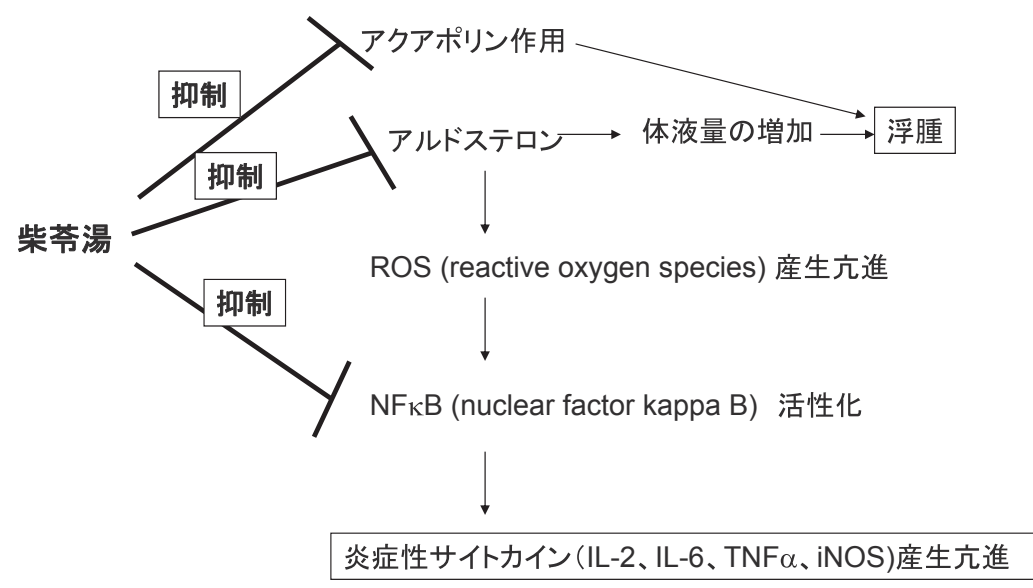

図 3 柴苓湯の浮腫・抗炎症作用に対する作用機序

(大阪大学大学院医学系研究科漢方医学寄附講座ホームページ改変) 
椠憼などの入った漢方薬を使いこなせば, 自由自在に 体感温度を調整できる。これは，西洋薬に無い漢方薬 の利点と言ってもよい.

また， [1][2]の症例のように, 主訴以外の症状も一 鼡で緩和することができるのも漢方薬の特徵である.

漢方薬エキス剂は, 多くの生薬を煎じているために, その含有する成分は多種多彩である。皇の特徵は, 漢 方薬の薬理作用を明らかにする際に一つの難関になっ ていることも確かであるが, 翻って臨床の現場では 「思いもかけない症状に効く」という利点をもたらす。 多数の疾患を合併している場合，たとえば高齢者には 漢方薬は有効な手段といってよい，西洋薬での対応は 一剤ずつ追加していくので薬の種類が増えがちである 点を考えると，単剤で安価な漢方薬を使いこなすこと は医療経済上も望ましいと言えよう。

同様に, 多岐にわたる漢方薬の効能を不定愁訴に応 用することも臨床上よく行う．種々の医療機関をたず ねても納得できない治療を受けられないために，“最 後の砦”のようにして漢方外来を訪れる例も多い。そ のため, 原疾患に伴う症状は勿論であるが，精神的に

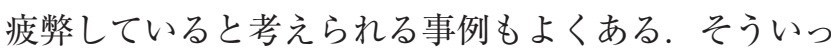
た症例では，厚朴や香附子など自律神経の機能失調を 改善する「理気薬」や，不安・不眠を改善する酸策 仁・遠志・童骨・牡蚛などの「安神薬」などの範疇に 入る生薬を含有する漢方薬をうまく用いることで, 精 神症状の改善をはかる.
[3]のケースを考えると, その漢方薬以外に, その症 状に効能を示す代替薬がない事例もある。こむらがえ りに頻用される芳薬甘架湯はその代表選手と言ってよ い.

以上が，筆者の考える，骨関節疾患に漢方薬を使う 意義である，最後に，東洋医学での診断は，問診や切 診に時間をかけ丁寧に行うので，診療プロセスさえも 有効な治療手段になりうる，といった西洋医学的アプ ローチとは違った利点がある.

著者の利益相反 : 岸田友紀（株式会社ツムラ）

\section{文献}

1) von Korffe M, et al. Br J Psychiatry. 1996;168:101-108.

2) 鈴木康之. ラジオ Nikkei. 2007.

3) 中永士師明. 日東医誌. 2008;59:809-812.

4) Takeda A, et al. Neurochem Int. 2008;53:230-235.

5) Kishida Y, et al. Phytomedicine. 2007;14:581-586.

著者プロフィール

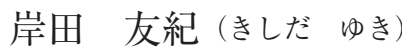

大阪大学大学院 医学系研究科 漢方医学寄附講座, 助教, 医学博 士 (大阪大学).

日本整形外科学会専門医 ・ 日本整形外科学会認定運動器リハビ リテーション医・日本東洋医学会専門医.

$\diamond$ 研究テーマ: 「老化と漢方薬」「運動器と漢方薬」. 